DOI https://doi.org/10.36059/978-966-397-160-5/34-49

\title{
POLITICAL DISCOURSE AS THE POWER INSTRUMENT: LINGUAL EXPLICIT AND IMPLICIT DEVISES OF THE MASS INFLUENCE
}

\section{Iryna Holubovska}

\section{INTRODUCTION}

Such terms as "political discourse", "political communication", "political concept" in our stormy times of climate, technological economical, social and political changes, when the whole model of the world is being transformed, have become the key words not only for linguistics, but also for sociology, political science, psychology, philosophy, etc. The multidisciplinary approach so much talked about in modern science might appear an effective tool to move from the analysis, which is widely used in various scientific branches to the synthesis of knowledge, to the creation of a holistic vision of an object that will emerge on the base of integration of already acquired knowledge about the subject, but already at the highest level of coherent cognition.

In the frames of modern anthropologically oriented linguistics the essence, nature and functions of political discourse are being researched on the crossroads of diverse areas of scientific knowledge. In addition to traditional rhetoric and stylistics, such branches of philology as linguosemiotics (Yu.S. Stepanov, R. Bart), pragmatic linguistics (N. Arutyunova, F. Batsevich, T. Van Dijk, V. Demyankov, O. Issers, K. Serazhym, R. Vodak), linguocultural studies and intercultural communication (V. Maslova, I. Sternin, S.Ter-Minasova), theory of communication (G. Pocheptsov, J.G. Mead, J. Walter, W. Fisher, M. McCombbs, D. Shaw) entered the circle of subject areas, within which political discourse is being studied. Scholars try to analyze the form, content, illocutions and perlocutions of political discourse, parameters of its effectiveness in the context of manipulative persuasive effect on the target audience. After all, any political discourse actualizes certain ideological 
views, establishes certain ideological constants which act as a certain markers of this or that particular ideological space ${ }^{1}$.

According to the concept of the well-known scholar of political reality, Jakob Torfing, political discourse represents the third phase in theory of discourse realization and might be defined as a relational system of meaning implementation determined by certain historical, economical, technological and other factors, which has the exclusive right to establish any social order within which "the Truth" is institutionalized (R. Bart, J. Derrida, J. Kristeva, J. Lacan, E. Laclo, S. Muff) ${ }^{2}$. According to such discourse understanding the main task for discourse analysis lies not in finding out how phenomena of the real world are reflected in language, but in tracing out how language constructs the phenomena: "discourse is the result of hegemonic articulations directed at the establishment of the both political and moral leadership in a society"3. Actually, "hegemonic articulations" are not able for self-implementation: they are introduced and rooted into the social and political life of this or that society in the result of manipulations with the sphere of people's subconsciousness. We understand manipulation as the hidden influence on the subconscious sphere of the addressee made by the sender of the message in order to control the consciousness and behaviour of the object of manipulative influence, which might be implemented with the help of both verbalized or nonverbalized devices" ${ }^{\text {. }}$

So, the purpose of political discourse could be defined in the terms of conquest and retention of power on the base of expanding a certain system of ideological views which might be rooted into the cognitive sphere of the target audience (electorate) through the explicit and implicit communicative influence. Within the frames of the modern political linguistics two approaches to the scale of meaning of the term "political discourse" are being outlined: a narrow and a broad ones. According to the first one, the notion of political institutional discourse is supposed to comprise the speeches of politicians, government documents, party programs, texts of parliamentary and pre-election debates, propaganda materials, etc. ${ }^{5}$. A broad

1 Tsutsieva M. G. (2012) Yazykovaya lichnost' kak sub»ekt politicheskogo diskursa. Vestnik Baltiyskogo federal’nogo universiteta im. I. Kanta, № 2, pp. 105.

2 Torfing J. (2005) Discourse Theory: Achievements, Arguments, and Challenges. Discourse Theory in European Politics. Identity, Policy and Governance. London: Palgrave Vacmillan, pp. 5-13

3 Levshenko Yu. I. (2012) Politicheskiy diskurs: Analiticheskiy obzor teoretikometodologicheskikh podkhodov Istoricheskie, filosofskie, politicheskie i yuridicheskie nauki, kul'turologiya i iskusstvovedenie. Voprosy teorii i praktiki, № 7, p. 105

${ }^{4}$ Kara-Murza S. G. (2005) Manipulyatsiya soznaniem. Moscow: Eksmo.

${ }^{5}$ Dejk T. van. (1989) Jazyk. Poznanie. Kommunikacija. Moscow: Progress, p. 26. 
understanding of political discourse implies the involvement of "discourse of reaction" into the above mentioned corpus, i.e. analytical articles of journalists, political scientists, public activists, bloggers, which are presented in social networks and deal with this or that particular event of the political

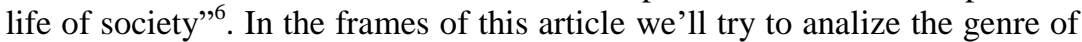
"primary communication", , turn to "political narrative", in which a politician becomes the key figure of political communication in the sense of spreading certain ideological views, which provide this or those meanings to the political events in order to form the ceratin public opinion and, accordingly, influence on the distribution and usage of power in the taken ethno-social community. Within this article, we'll study political institutional discourse created by the politician as a representative of a certain institution (administration, party, parliament, etc., or made by one of the speechwriters belonging to his "team") on the base of such genre as inaugural speech. The inaugural speech, as one of the genres of institutional political discourse, is of particular interest for several reasons: 1) it contains certain meanings and senses that represent the ideological and political positions of the President who takes office; 2) it is an official programmatic appeal to the nation and the world; 3) it is characterized by a high degree of persuasiveness, appealing to both rational and emotional spheres; 4) it contains implications and latent meanings, which are often firmly rooted in a system of national values of this or that ethnic community.

Thus, the object of our investigation is inaugural speech as a genre of political communication; the subject is formed by lingual and non-lingual peculiarities of tactics actualization which implement a general manipulative strategy of politician's speech and are deployed in the text on the base of national-cultural, political-social and spiritual-ethical values inherent in this or that ethnic community.

Values will be understood as a system of internalized in the collective national consciousness, stable for the certain period of time, culturally determined concepts, attitudes, perceptions, beliefs, which are recognized as correct and effective for ensuring the functioning of the individual in society. Values, being of ideal character, are exteriorized through certain statements and actions of people.

\section{Methodology and methods}

Such terms-notions as "communicative strategy", "communicative tactics", "communicative move" will be used as those which have a long

\footnotetext{
${ }^{6}$ Sheygal E. I. (2004) Semiotika politicheskogo diskursa. Moscow: ITDGK «Gnozis», p. 23

${ }^{7}$ Bahtin M. M. (1986) Jestetika slovesnogo tvorchestva. Moscow: Iskusstvo, p. 279.
} 
history of institutionalization in the frames of linguistic pragmatics ${ }^{8}$. The "working content" of these terms in this article is: communicative strategy is the general plan of communication, subordinated to the practical goals of the speaker; communicative tactics then is a way of implementing a communicative strategy; communicative move implies the content of verbal / non-verbal actions of the speaker aimed at achieving the communicative goal. Thus, these three terms are in generic-species relationship.

Basing on the approaches to manipulative strategies and tactics distinction which have already been developed in the modern political linguistics ${ }^{9}$, we propose our own vision, according to which a manipulative strategy implies the evolution of such tactics as: 1) argumentation; 2) identification; 3) intimization; 5) positive self-presentation; 6) accusation; 7) sacred symbolization; 8) social efforts' integration and encouragement to cooperate with the authorities; 9) positive forecasting.

The inaugural speech of President Donald Trump, 45th President of the United States of America would serve as an empirical stuff for this article. Such methods of linguistic analysis are being used: descriptive method, method of contextual and component analysis, discourse-analysis, conceptual analysis, method of presuppositions, method of language data cultural interpretation, linguopragmatic method.

\section{Results and discussion}

In the beginning of his speech, Donald Trump addressed the words of gratitude not only to the American people, but for the first time in the history of this genre of public speaking in USA, appealed to all the people of the world: "Chief Justice Roberts, President Carter, President Clinton, President Bush, President Obama, fellow Americans and people of the

\footnotetext{
${ }^{8}$ Bacevych F. S. (2004) Osnovy komunikatyvnoi’ lingvistyky Kyev, Issers O. S. (2008) Kommunikativnye strategii i taktiki russkoy rechi. Izd. 5-e. Moscow: URSS, Snitko O. S., Vasilenko N. V. (2013) Russkiy yazyk kak deyatel'nost':sovremennye napravleniya nauchnogo opisaniya. Tekst lektsiy. Kyi'v: Izdatel'sko-poligrafichekiy tsentr «Kievskiy universitet».

${ }^{9}$ Dmytruk O. V. (2006) Manipuljatyvni strategii' v suchasnij anglomovnij komunikacii' (na materiali tekstiv drukovanyh ta Internet-vydant 2000-2005 rokiv): avtoref. dys. kand. filol. nauk, Kyi'v, Dotsenko E. L. (1997) Psikhologiya manipulyatsii: fenomeny, mekhanizmy i zashchita Moscow: CheRo, MGU, Kondratenko N. V. (2009) Komunikatyvni strategii' v ukrai'ns'komu politychnomu dyskursi: interaktyvna vzajemodija uchasnykiv politychnyh tokshou. Dialog: Media-studii', vol. 8, pp. 48-58, Mikhaleva O. L. (2004) Politicheskiy diskurs kak sfera realizatsii manipulyativnogo vozdeystviya: avtoref. diss. kand. filol. nauk, Kemerovo, Pirogova Yu. K. (2001) Implitsitnaya informatsiya kak sredstvo kommunikativnogo vozdeystviya i manipulirovaniya. Problemy prikladnoy lingvistiki. Moscow, pp. 209-227.
} 
world, thank you" "10. We see here an implicitly implemented tactic of social efforts' integration and encouragement to cooperate with the authorities, addressed not only to American citizens but also to all of the inhabitants of the planet the Earth: it is implemented with the help of communicative move of thanksgiving.

The next line reveals the presupposition of the destruction in material and spiritual ways of US citizens' lives (apparently destructed during the two previous cadences of Barack Obama), therefore America must unite efforts not only "to rebuild our country", but also "to restore its promise for all of our people": "We, the citizens of America, are now joined in a great national effort to rebuild our country and restore its promise for all of our people". Thus, on the one hand, the tactics of accusation of the previous administration in the country's collapse and destruction of promises given to the people is being implemented, - on the other hand, the tactic of intimization is actualized with the help of communicative move of the president's self-presentation as a part of the whole nation: "We, the citizens of America...". The communicative move is realized by the syntagmatic supposition of the personal pronoun (the first person plural) we and the collective noun citizens.

Further, the president, discursively developing such an American value, as "Future Orientation / Optimism"" , expresses a positive belief that the course of his administration, being coherent to the hopes of the American people and again! to the hopes of the "peoples of the world", will overcome all challenges and be a success: "Together, we will determine the course of America and the world for many, many years to come. We will face challenges. We will confront hardships. But we will get the job done". The affirmative character of this statement is supported by a fourfold parallel repetition of a single syntactic structure with grammatical semantics of future, such as: Pron + aux.verb will + main verb + noun, $\mathbf{S}-\mathbf{P}-\mathbf{D O}$ : "We will determine the course of America...; "We will face challenges", "We will confront hardships"; "We will get the job done". The tactic of intimization is here effectively combined with the tactics of positive

10 http://edition.cnn.com/2017/01/20/politics/trump-inaugural-address/index.html;https:// zbruc.eu/ node/ 61279

${ }^{11}$ Kohls L. R. (1984) The Values Americans Live By. In our further research, we will refer to the value system of Americans proposed by Robert Kohls in his article "The Values Americans Live By" (1984). He highlights such values as: 1) change/mobility; 2) personal control over the environment; 3) time and its control; 4) equality/equalitarism; 5) individualism, independence and privacy; 6) self-help; 7) competition and free enterprise; 8) future orientation/optimism; 9) action and work orientation; 10) informality; 11) directness, openness, honesty; 12) practicality/efficiency; 13) materialism/acquisitiveness and others. 
forecasting. Actually, in this place of the studied inaugural speech we are coming across the well-known logical structure of tricolon: "thesis antithesis -synthesis", which had been widely used since times of antiquity in the speeches of Cicero, Demosthenes, Socrates (the most famous example is "Veni, vidi, vici"). Within this syntactic iterance, verbal phrases of negative / ambivalent semantics: "antithetical" face challenges, confront hardships are opposed to the "synthetical" verbal phrase with positive evaluative coloring: get the job done. All this stuff creates a rhythmicsemantic balance necessary for inducing of the suggestive effect within the studied paragraph.

In accordance with the postulates of the courtesy formulated by LeechGrays $^{12}$, Trump thanked President Barack Obama and his wife Michel for their support and assistance in the transition of power: "Every four years we gather on these steps to carry out the orderly and peaceful transfer of power. And we are grateful to President Obama and first lady Michelle Obama for their gracious aid throughout this transition. They have been magnificent. Thank you". While thanking, he uses words and phrases of positive rational axiology: the orderly and peaceful transfer of power, grateful, gracious help, magnificent. Of course, we are not regarding politeness as a phenomenon which belongs to the values of American lingual culture, but it might be qualified as a very important distinctive feature of American speech behaviour (let's recall the famous American smile, without which it's really hard to imagine interpersonal communicative process in American way). Nevertheless tactics of politeness was not implemented here in view of the specifics of the next paragraph discursively-evaluative deployment, which appears to be in the sharp contrast with the previous one: "Today's ceremony, however, has a very special meaning because today we are not merely transferring power from one administration to another or from one party to another, but we are transferring power from Washington, D.C., and giving it back to you, the people". This paragraph nullifies all the figures of courtesy that are characteristic for the preceding paragraph and realize at the textual level a kind of mega-syntactic antithetical construction. In fact, D. Trump, discursively actualizing such American value as "Directness, Openness, Honesty", publicly acknowledges that during the cadences of many previous presidents of America power belonged not to the people but to the narrow elite political circles, to the American establishment, which defended exclusively their own political and economical interests: "For too long, a small group in our nation's capital has reaped the rewards of government while the people have borne the cost. Washington flourished,

\footnotetext{
${ }^{12}$ Leech G. N. (1983) Principles of Pragmatics. London: Longman.
} 
but the people did not share in its wealth. Politicians prospered but the jobs left and the factories closed. The establishment protected itself, but not the citizens of our country. Their victories have not been your victories. Their triumphs have not been your triumphs. And while they celebrated in our nation's capital, there was little to celebrate for struggling families all across our land".

Manipulative influence is carried out here due to the verbalization of the antithetic opposition between the political elite of American society and ordinary Americans, in other words the archaic opposition "own" - "alien" serves as a basis for gaining people's benevolence: "a small group in our nation's capital has reaped the rewards of government" - "the people have borne the cost", "Washington flourished" - "people did not share in its wealth", "Politicians prospered" - "the jobs left and the factories closed", "The establishment protected itself" - "not the citizens of our country", "while they celebrated in our nation's capital" - "there was little to celebrate for struggling families all across our land". Thus, "aliens" for ordinary Americans and, as it comes, for Trump himself (which identifies himself and common people with the help of intimization tactic embodied verbally by the personal pronoun in plural-we ) receive nominations: a small group, Washington, politicians, the establishment, they. The category of "own" is verbalized by such nomens and phrases: the people, the citizens, struggling families all over our land. The rhetorical effect of the antithesis is realized not only on the lexical, but also on the microsyntactic and macrosyntactic levels with the help of three time iteration of the same model of complex sentence with the opposite conjunction but according to the model: S - Pplus, but $\mathbf{S}$ - Pminus, within which the subject of the first part of the sentence is characterized by verbal predicate with positive estimated value: flourished, prospered, protected, and the subject of the second part of the sentence, on the contrary, receives the predicate attribution of generally negative evaluation: borne the cost, left (jobs), closed (the factories), not to protect (the citizens). Thus, the communicative move of antithesis embodies the communicative tactics of accusation and intimization.

The following paragraph "exploits" such American value as "Equality/Equalitarism": "That all changes starting right here and right now, because this moment is your moment. It belongs to you. It belongs to everyone gathered here today and everyone watching all across America. This is your day. This is your celebration. And this, the United States of America, is your country. What truly matters is not which party controls our government, but whether our government is controlled by the people. January 20th, 2017, will be remembered as the day the people became the 
rulers of this nation again. The forgotten men and women of our country will be forgotten no longer. Everyone is listening to you now. You came by the tens of millions to become part of a historic movement, the likes of which the world has never seen before. At the center of this movement is a crucial conviction that a nation exists to serve its citizens. Americans want great schools for their children, safe neighborhoods for their families, and good jobs for themselves. These are just and reasonable demands of righteous people and a righteous public".

It is a common knowledge that equality stands for one of the most fundamental values of American constitutionalism, alongside with freedom and democracy. Just at the moment of his inaugural speech Trump highlights "transferring" power to the American people: this moment is your moment, putting it in one raw with positively marked notions like: celebration, country, historic movement, righteous people, a righteous public. Frequent repetition of the possessive pronoun of the second person plural your promotes the development of the semantics of "appropriation": your day, your celebration, your country. In this way an emotionally marked communicative tactics of intimization is realized, illusory reduction of distance between the authorities and the people is achieved. Thus, the necessary foundation for the implementation of the tactics of positive selfpresentation is being created. However, according to Trump's vision, before this historic moment, that is, during the two cadences of B. Obama, the forty-fourth president of the United States (January 20, 2009 January 20, 2017), the USA was declining: "But for too many of our citizens, a different reality exists. Mothers and children trapped in poverty in our inner cities, rusted out factories scattered like tombstones across the landscape of our nation. An education system flush with cash but which leaves our young and beautiful students deprived of all knowledge. And the crime and the gangs and the drugs that have stolen too many lives and robbed our country of so much unrealized potential. This American carnage stops right here and stops right now".

The idea of America's decline is verbalized with the help of words and phrases of general-negative semantics: "mothers and children trapped in poverty", "rusted out factories scattered like tombstones", "students deprived of all knowledge", "the crime, the gangs, the drugs", "stolen lives", "robbed country", "unrealized potential", "American carnage".

Tactic of accusation in unsuccessful domestic politics addressed to the administration of B. Obama is implicitly implemented here. The final phrase of this paragraph: "This American carnage stops right here and stops right now" comes into structural resonance with the initial one: “... all changes 
starting right here and right now", fixing definite political labels: pejorative "carnage" - for "before-Trump" America, meliorative "changes" - as a key word for "Trump's America",

The following paragraph implements the communicative tactic of intimization and appeal to cooperate with the authorities on the basis of common democratic values, which is carried out with the help of the communicative move identifying pain, dreams, the success of the people: their pain, their dreams, their success with pain, dreams, the success of country's political elite: our pain, our dreams, our success: We are one nation, and their pain is our pain. Their dreams are our dreams, and their success will be our success. We share one heart, one home, and one glorious destiny. The oath of office I take today is an oath of allegiance to all Americans. And here again, we see the implicit realization of the "old American value" "Equality/Equalitarism".

Further, in the next paragraph, the archetypal opposition "own-alien" is once again implicitly actualized with the help of opposing American industry, army, middle class, workers (suffering from ineffective domestic policy of the previous administration) - to the outside world (foreign industry, armies of the foreign countries): "For many decades we've enriched foreign industry at the expense of American industry, subsidized the armies of other countries while allowing for the very sad depletion of our military. We've defended other nations' borders while refusing to defend our own. And we've spent trillions and trillions of dollars overseas while America's infrastructure has fallen into disrepair and decay. We've made other countries rich while the wealth, strength and confidence of our country has dissipated over the horizon. One by one, the factories shuttered and left our shores with not even a thought about the millions and millions of American workers that were left behind. The wealth of our middle class has been ripped from their homes and then redistributed all across the world". Such kind of politics contributed to the outflow of capital from the US lefting the ordinary citizens unprotected. In this paragraphs we again come across the implicitly implemented tactic of accusation.

However, President D. Trump promises to leave in the past the policy of "alien's" support: "but that is the past", and in the future, "from this day forward", a new concept of country's development will be proposed: "a new vision will govern our land", the essence of which might be formulated as "America first, America first". And again, just as in the beginning of his speech, Donald Trump emphasizes that he wants to be heard not only by

13 "Change" stands for one of the most valid_values of Americans and as a socially and politically determined concept of American mentality is still waiting for its researcher. 
Americans, but also by other peoples of the world and their authorities. To increase his speech's impact, the iteration of the pronoun every is used, every new time being combined with a word or a phrase having more semantic significance in comparison with the previous one: "to be heard in every city, in every foreign capital, and in every hall of power". The communicative tactics of positive forecasting is implemented here.

The new state policy will lead to unprecedented victories of America which will be caused by the development of national economy and infrastructure, by the restitution of jobs, wealth, and, more importantly, dreams. AMERICAN DREAM is a concept of American mentality based on American ideals and values (democracy, freedom, equal opportunity) and is aimed at positive prediction of the future material prosperity / success regardless of social origin and achieved only thanks to tense everyday work: "America will start winning again, winning like never before. We will bring back our jobs. We will bring back our borders. We will bring back our wealth, and we will bring back our dreams. We will build new roads and highways and bridges and airports and tunnels and railways all across our wonderful nation. We will get our people off of welfare and back to work, rebuilding our country with American hands and American labor. We will follow two simple rules: buy American and hire American. We will seek friendship and goodwill with the nations of the world, but we do so with the understanding that it is the right of all nations to put their own interests first. We do not seek to impose our way of life on anyone, but rather to let it shine as an example. We will shine for everyone to follow. We will reinforce old alliances and form new ones and unite the civilized world against radical Islamic terrorism, which we will eradicate completely from the face of the earth".

Within the frames of this paragraph, tactics of positive forecastiong is embodied with the help of an anaphorical syntactic partial iteration aimed to increase the emotional impact. Anaphora usually draws the attention to the speaker's primary goal.

In the following presentation D. Trump uses a communicative tactics of sacred symbolism on the ground of biblical idea of people accord identification with unity of the country, solidarity of its citizens, idea of protection, which in this case would be provided by the powers of heaven and earth: "The Bible tells us how good and pleasant it is when God's people live together in unity. We must speak our minds openly, debate our disagreements honestly, but always pursue solidarity. When America is united, America is totally unstoppable. There should be no fear. We are protected and we will always be protected. We will be protected by the great 
men and women of our military and law enforcement. And most importantly, we will be protected by God". It is commonly known, that wish to be protected is one of the most fundamental human needs ${ }^{14}$.

In the next paragraph in the frames of communicative tactics of accusation, such an American value as "Action/ Work Orientation" is being actualized, when the previous administration is implicitly accused of lack of scale of thinking, petty dreams and absence of political will for radical action: Finally, we must think big and dream even bigger. In America, we understand that a nation is only living as long as it is striving. We will no longer accept politicians who are all talk and no action, constantly complaining but never doing anything about it. The time for empty talk is over. Now arrives the hour of action.

In the end of his speech, Trump appeals to such fundamental for all of Americans psychological constants (which also refer to emotional and teleonomic national values) as patriotism: national pride, spirit of America, our soldiers, red blood of patriots, glorious freedoms, great American flag) and trust in God: night sky, almighty Creator). At the same time, the manipulative communicative tactics of identification and sacred symbolization are discursively developed: "Do not allow anyone to tell you that it cannot be done. No challenge can match the heart and fight the spirit of America. We will not fail. Our country will thrive and prosper again. We stand at the birth of a new millennium, ready to unlock the mysteries of space, to free the earth from the miseries of disease, and to harness the energies, industries, and technologies of tomorrow. A new national pride will stir ourselves, lift our sights, and heal our divisions. It's time to remember that old wisdom our soldiers will never forget, that whether we are black or brown or white, we all bleed the same red blood of patriots. We all enjoy the same glorious freedoms and we all salute the same great American flag. And whether a child is born in the urban sprawl of Detroit or the windswept plains of Nebraska, they look up at the same night sky, they fill their heart with the same dreams, and they are infused with the breath of life by the same almighty Creator". Here, as we have already said, the tactics of identification (Tramp identifies himself with voters, with changes, with the past and future of America) is gradually replaced by the tactics of sacred symbolization. It has been applied on the background of comprehensive intimazation (personal pronouns we, our; determinator the same) with the help of a multistage epiphoric iteration ${ }^{15}$,

\footnotetext{
14 Maslow A. H. (1954) Motivation and Personality. New York: Harpaer \& Row Publishers, Inc.

15 Epiphora is anti-thetic to anaphora, it focuses attention of the addressee on the consequences of actions, on their desired result.
} 
within the framework of which a marker of identification and association the same is used to raise the 45th President of America and the whole country to the level of the Absolute: "We all bleed the same red blood of patriots. We all enjoy the same glorious freedoms and we all salute the same great American flag. And whether a child is born in the urban sprawl of Detroit or the windswept plains of Nebraska, they look up at the same night sky, they fill their heart with the same dreams, and they are infused with the breath of life by the same almighty Creator". In this case, the syntagmatic chain is built up, within which the usage of attributive phrases: the same red blood of patriots $>$ the same glorious freedoms $>$ the same great American flag > the same night sky > the same dreams > the same almighty Creator is aimed to mark the glorious history of America beginning from the times of gaining independence, struggle for democratic freedoms, Declaration of Independence, American dream concept formation -up to this inaugural day, which was initiated (in D. Trump's interpretation) by the grace of the Creator. In a simple sentence they (children) look up at the same night sky the contours of the Kantian precedential text come to light: "Two things in the world fill my soul with sacred awe - the starry sky overhead and the moral law within us" (I. Kant).

And finally, D. Trump, referring only to American citizens (and not to people all over the world as in the beginning of his speech), applies in parallel the tactics of accusation and tactics of positive forecasting: "So to all Americans in every city near and far, small and large, from mountain to mountain, from ocean to ocean, hear these words: You will never be ignored again. Your voice, your hopes, and your dreams will define our American destiny. And your courage and goodness and love will forever guide us along the way. Together we will make America strong again, we will make America wealthy again, we will make America proud again, we will make America safe again. And, yes, together we will make America great again. Thank you. God bless you. And God bless America".

The tactics of positive forecasting is embodied in nouns and adjectives with semantics of positive evaluation, such as: hopes, dreams, courage, goodness, love; strong, wealthy, proud, safe, great. An epiphoric iteration with gradual increasing of the degree of abstraction (from a strong, rich, safe country to the Great America) developed on the background of the ultimate intimization (you, your, we, together) might be qualified as is a key generalizing moment of the studied inaugural speech of the President D. Trump. 


\section{CONCLUSIONS}

1. Politics is a form of language use that is primarily aimed at proclaiming and promoting a certain system of values and ideals in society.

2. The President, as a leader of public opinion within the certain country, and in the case of developed democracies (USA, France) -in the world, in the framework of the inaugural speech represents a system of ideologemes that will determine the social being of society in the nearest future.

3. Being sacredly and ritually determined, the inaugural speech aims to convince the addressee of the correct choice of the new head of the country, therefore, it is characterized by a high degree of persuasiveness, which is realized by the use of communicative tactics and appeal to the socio-political and national-cultural values of the electorate.

4. The purpose of political discourse is in the conquest and retention of power with the help of a certain system of ideological views which are rooted into the cognitive sphere of the electorate through the explicit and implicit communicative influence.

5. The analysis of the inaugural speech of the 45th President of the United States, Donald Trump, demonstrated the use of certain communicative tactics within general manipulative strategy: 1) argumentation; 2) identification; 3) intimization; 5) positive selfpresentation; 6) accusation; 7) sacred symbolization; 8) social efforts' integration and encouragement to cooperate with the authorities; 9) positive forecasting, -realized by means of this or those communicative move. As a rule, the verbalizations of communicative moves is realized with the help of such stylistic figures as anaphora and epiphora, which embody certain communicative intentions of the addressee. Our analysis discovered no logical or rational arguments, vice versa, the speaker tries to get the audience's support appealing mostly to its emotional sphere. All communicative tactics which implement a manipulative strategy of influence on the electorate implicitly rely on Americans' political, social, spiritual and ethical values, such as: "Future Orientation/Optimism", "Equality/Equalitarism", "Action and Work Orientation", "Directness, Openness, Honesty"; "Change".

\section{SUMMARY}

The article deals with the political institutional discourse as an instrument for influencing the masses and manipulating their consciousness, moods, behavior in the interests of a small group of people who call themselves the political elite of society. On the empirical material of the inaugural speech of the 45th President of the United States of America 
Donald Trump such communicative tactics as: argumentation; identification; intimization; positive self-presentation; accusation; sacral symbolization; social efforts' integration and encouragement to cooperate with the authorities; positive forecasting -have been highlighted. Ethical and spiritual values of the American people (such as: "Future Orientation/Optimism", "Equality/Equalitarism", "Action and Work Orientation", "Directness, Openness, Honesty"; "Change") serve as the implicit basis for the discursive actualization of communicative tactics used by the politician for reaching his communicative purposes. Evidently, the structure of the manipulative influence embodied in the political text of inaugural genre on the verbalsemantic and deep-cognitive levels of its analysis would have the same character. In prospective it must be proved on the basis of a study of political speeches of other politicians belonging to different political cultures.

\section{REFERENCES}

1. Arhypova Je. O. (2007) Vykorystannja manipuljatyvnoi' strategii' komunikacii' v informacijnomu suspil'stvi [переклад], novyn.kpi.ua/20072-2/16_Arhipova.pdf

2. Bart R. (1994) Mif segodnja: Izbrannye raboty. Moscow: Progress, pp. 72-130.

3. Bahtin M. M. (1986) Jestetika slovesnogo tvorchestva. Moscow: Iskusstvo, $445 \mathrm{pp}$.

4. Bacevych F. S. (2004) Osnovy komunikatyvnoi’ lingvistyky Kyev, $342 \mathrm{pp}$.

5. G'rajs G. (1985) Logyka y rechevoe obshhenye. Novoe v zarubezhnoj lyngvystyke: Lyngvystycheskaja pragmatyka, vol. XVI, pp. 217-237.

6. Danylenko O. S. (2014) Ponjatye y osobennosty polytycheskogo dyskursa Naukovi zapysky NDU im. M. Gogolja. Filologichni nauky, kn. 2, pp. 62-66, irbis-nbuv.gov.ua/cgi-bin/irbis_nbuv/cgiirbis_64.exe

7. Dejk T. van. (1989) Jazyk. Poznanie. Kommunikacija. Moscow: Progress, $312 \mathrm{pp}$.

8. Dmytruk O. V. (2006) Manipuljatyvni strategii’ v suchasnij anglomovnij komunikacii' (na materiali tekstiv drukovanyh ta Internetvydant 2000-2005 rokiv): avtoref. dys. kand. filol. Nauk, Kyi’v, 19 p.

9. Dotsenko E. L. (1997) Psikhologiya manipulyatsii: fenomeny, mekhanizmy i zashchita Moscow: CheRo, MGU, 344 p.

10. Issers O. S. (2008) Kommunikativnye strategii i taktiki russkoy rechi. Izd. 5-e. Moscow: URSS, 288 p. 
11. Kondratenko N. V. (2009) Komunikatyvni strategii' v ukrai'ns'komu politychnomu dyskursi: interaktyvna vzajemodija uchasnykiv politychnyh tok-shou. Dialog: Media-studii', vol. 8, pp. 48-58.

12. Kara-Murza S. G. (2005) Manipulyatsiya soznaniem. Moscow: Eksmo, 832 pp.

13. Kostyunina M. V. (2014) Lingvoritoricheskie osobennosti predvybornykh rechey B. Obamy (2008 g.). Politicheskaya kommunikatsiya: perspektivy razvitiya nauchnogo napravleniya. Ekaterinburg, pp. 131-136.

14. Levshenko Yu. I. (2012) Politicheskiy diskurs: Analiticheskiy obzor teoretiko-metodologicheskikh podkhodov Istoricheskie, filosofskie, politicheskie $i$ yuridicheskie nauki, kul'turologiya $i$ iskusstvovedenie. Voprosy teorii $i$ praktiki, № 7, pp. 100-108, http://cyberleninka.ru/ article/n/politicheskiy-diskurs.

15. Maslova V. A. (2008) Politicheskiy diskurs: Yazykovye igry ili igry v slova? Politicheskaya lingvistika, vol. 1 (24), pp. 43-48.

16. Mikhaleva O. L. (2004) Politicheskiy diskurs kak sfera realizatsii manipulyativnogo vozdeystviya: avtoref. diss. kand. filol. nauk, Kemerovo, $24 \mathrm{pp}$.

17. Neoritorika: genezis, problemy, perspektivy (1987). Sbornik nauchno-analiticheskikh obzorov. Moscow: MGU, pp. 46-79.

18. Perel'gut N. M., Sukhotskaya E. B. (2013) O strukture ponyatiya «politicheskiy diskurs». (2013) Vestnik Nizhnevartovskogo gosudarstvennogo universiteta, vol. 2, http://cyberleninka.ru/article/n/ostrukture-ponyatiya-politicheskiy-diskursi.

19. Pirogova Yu. K. (2001) Implitsitnaya informatsiya kak sredstvo kommunikativnogo vozdeystviya i manipulirovaniya. Problemy prikladnoy lingvistiki. Moscow, pp. 209-227.

20. Pochepcov G. G. (1999) Teorija komunikacii', 2-e vyd., Kyi’v: Vyd. centr "Kyi'vs'kyj universytet", 308 pp.

21. Cnitko O. S., Vasilenko N. V. (2013) Russkiy yazyk kak deyatel'nost':sovremennye napravleniya nauchnogo opisaniya. Tekst lektsiy. Kyi'v: Izdatel'sko-poligrafichekiy tsentr «Kievskiy universitet», $159 \mathrm{pp}$.

22. Tsutsieva M. G. (2012) Yazykovaya lichnost' kak sub»ekt politicheskogo diskursa. Vestnik Baltiyskogo federal'nogo universiteta im. I. Kanta, № 2, pp. 104-107.

23. Sheygal E. I. (2004) Semiotika politicheskogo diskursa. Moscow: ITDGK «Gnozis», $326 \mathrm{pp}$.

24. Van Dijk T. A. (1998) What is Political Discourse Analysis, http://www.discourse-in-society.org 
25. Van Dijk T.A. (2006) Discourse and Manipulation, Discourse \& Society, vol. 17, pp. 359-383.

26. Fairclough N. (2003) Analysing Discourse: Textual Analysis for Social Research. London: Routledge.

27. Kohls L. R. (1984) The Values Americans Live By, http://www1.cmc.edu/pages/faculty/alee/extra/American_values.html.

28. Leech G. N. (1983) Principles of Pragmatics. London: Longman.

29. Maslow A. H. (1954) Motivation and Personality. New York: Harpaer \& Row Publishers, Inc.

30. Torfing J. (2005) Discourse Theory: Achievements, Arguments, and Challenges. Discourse Theory in European Politics. Identity, Policy and Governance. London: Palgrave Vacmillan, pp. 23-47.

31. Wodak R. (1989) Language, power and ideology. London: Academic Press.

\section{Information about the author:}

Iryna Holubovska,

PhD, Full Professor,

Head of the Chair of General Linguistics,

Classical Philology and Neohellenistics, Institute of Philology,

Taras Shevchenko National University of Kyiv 60, Volodymyrs'ka str., Kyiv, 02000, Ukraine 